\title{
Disability Studies
}

Canadian Journal of Disability Studies

Published by the Canadian Disability Studies Association Association Canadienne des Études sur le Handicap

Hosted by The University of Waterloo

www.cjds.uwaterloo.ca

cjdseditor@uwaterloo.ca 
Georgia van Toorn, (2021). The New Political Economy of Disability: Transnational Networks and Individualised Funding in the Age of Neoliberalism. Abingdon, UK: Routledge. ISBN: 9780-3674-8305-0

Karen Soldatic, (2019). Disability and Neoliberal State Formations. Abingdon, UK: Routledge. ISBN: 978-1-4724-6018-9

\author{
Reviewed by \\ Ravi Malhotra, S.J.D. \\ Full Professor \\ Faculty of Law, Common Law Section \\ University of Ottawa \\ ravi.malhotra[at]uottawa.ca
}

Two recent disability studies monographs from Routledge devoted in part to the Australian state and its policies with respect to disabled people break exciting new ground in analyzing the economic marginalization of disabled people and how to empower them. Both volumes are creative, well-researched, and thoughtful contributions to disability studies because of the questions they pose and the insightful, novel ways they encourage us to think about the questions. The New Political Economy of Disability: Transnational Networks and Individualised Funding in the Age of Neoliberalism by Georgia van Toorn explores the career of the concept of individualised funding (IF) for disabled people across three nations, England, Scotland, and Australia. Employing both an interdisciplinary theoretical perspective and empirical research on the ground, she shows how IF, which allows disabled people to purchase services for assistance with activities of daily living by giving them direct payments, is an example of "policy mobility" across nation-states with which disability rights advocates have engaged at their peril. Disability and Neoliberal State Formations by Karen Soldatic traces how disability policy in Australia has changed over time as the privatization and market-oriented policies of successive Australian governments reshaped agendas to serve the new dogma of neoliberalism. Each book is well 
worth reading on its own and together they offer the reader some of the best cutting edge critical disability theory I have had the chance to read in some time.

Originating in a doctoral dissertation she wrote at the University of New South Wales and co-supervised by none other than Karen Soldatic, van Toorn explores how Australia has adopted IF concepts and frameworks developed earlier in England and Scotland. She seeks to answer how and why IF has taken hold in the Australian disability sector. In doing so, she illustrates how the concept of "policy mobility" is a facet of neoliberalism by which a transnational network of mobile "government and non-government actors, including advocates, activists, consultants and expert communities" (p. 4) operate in tandem to encourage policies that strengthen market values across states. The book contains eight chapters and an introduction. The first chapter offers an intellectual history of IF as a concept and a defence of her policy mobilities approach. Chapters Two and Three examine the development of IF in England under first the Conservative government of John Major and then the long rule of New Labour between 1997 and 2010. Chapters Four and Five are devoted to evaluating the Scottish case. The author demonstrates how despite more progressive policy discourse in Scotland emphasizing social participation and human rights, financial austerity ultimately trumped the decision-making process on the ground. Chapters Six and Seven examine the transplantation of IF to Australia. The author discusses how a focus on "individual choice" resonated with disability rights advocates but led to the marketization of services in a manner that undermines the rights and dignity of disabled people. Chapter Eight provides an assessment of the transnational character of IF and its relationship to neoliberalism. Consistently ambitious and thought-provoking, van Toorn's book is precisely the kind of sophisticated political economy analysis that disability studies so badly needs. 
One of the most important contributions of van Toorn's book is her thoughtful engagement on how social movements of the New Left including disability rights advocates engaged with neoliberal discourse in order to promote policies such as IF. As she puts it many progressive disability rights advocates shared an "elective affinity with certain neoliberal ideals and policies" (p. 6). Her analysis of disability organizations such as In Control is apt and timely, documenting how an initial commitment to equality and social justice gave way to the need to prioritize particular individuals due to financial constraints and budget-cutting. Apart from a handful of exceptions such as Marta Russell and Samuel Bagenstos, very few disability scholars have analyzed this neoliberal aspect of the mainstream disability rights movement. Focusing on autonomy, independent living and a refusal to rely on state bureaucracies too often elides how neoliberal capitalism leaves most disabled people, especially women, Indigenous people, and racialized people, living in poverty. While there is no doubt consumer choice and the freedom it enables for disabled people are real gains that ought to be celebrated, von Toorn demonstrates that two features of IF in the three nations under study are compulsory budgeting and the creation of the services by social care and rehabilitation professionals. These coercive developments are of course troubling from the perspective of the social model which stands for the proposition that services should be designed and directed by disabled people to meet their needs as they deem fit.

A second strength of van Toorn's monograph is the comparative framework, distilling insights, and experiences from three nations. Too many disability rights advocates and scholars know almost nothing about policy developments relating to independent living and IF in other countries. She insightfully shows how despite Scotland's commitment to an egalitarian political culture and solidaristic welfare policy, the actual policy resulted in cuts of eleven percent in the 
four years leading up to the passage of the Social Care (Self-directed Support) Act in 2014. She sensitively documents how issues became reframed so that the neoliberal discourse of not relying on the state-dominated civil society. Canadian disability rights advocates would benefit from greater knowledge of how IF operates on the ground in other countries as discussed in this volume, especially given the longstanding historic links to these nations through the Commonwealth. My one reservation is van Toorn does not devote space to analyzing the economic conditions faced by workers who provide care. The legal issues relating to the regulation of attendant service workers are complex and warrant detailed commentary. While this may reflect deliberate decisions on the scope of her project, future researchers need to include the voices of attendant services workers in order to fully understand the impact of neoliberalism in this sector.

Soldatic, a well-known disability scholar, has produced yet another impressive monograph devoted to disability and neoliberalism in Australia. This short monograph contains six chapters, some of which have been previously published in journals. Chapter 1 provides an introduction to state formations in the Australian context. Materialist analysis of disablement has focused on the relationship between the capitalist mode of production and the creation of impairment. Scholars such as Oliver, Gleeson, and Russell have developed compelling accounts on this basis. Idealist theorists including Garland-Thomson and Siebers have focused on the cultural representation of the impaired body. Soldatic wisely argues that theorists should transcend the idealist-materialist debates in disability studies and instead work toward understanding a neoliberal moral economy of disability. In so doing, Soldatic makes a genuine contribution to the literature. 
In Chapter 2, Soldatic explores neoliberal disability reclassification in the conservative Howard government (1996-2007) and then in the Rudd-Gillard Labor governments. She demonstrates how the policy instrument known as Case Based Funding (CBF) engaged in creaming: focusing on the least impaired people in order to make outcomes look better while cutting spending on disabled people overall. The Howard government pursued a strategy of coopting disability rights rhetoric while endorsing austerity and workfare. This was symbolized by reassigning disability employment policy away from disability bureaucrats to the Department of Employment and Workplace Relations. This corresponded with a shift in disabled people's labour market participation from full-time employment to casual part-time employment in the contingent labour market. At the same time, the Howard government strengthened the segregationist and exploitative sheltered workshops, rebranding them as Business Services and Social Enterprises (p. 27). The sheltered workshops, with the backing of some family members of disabled people, engaged a corporate law firm to defend their industry. Despite minor changes, the Labor government entrenched the strategy of moving disabled people off income supports and into competitive employment.

Chapter 3 is a highly creative intervention, a considered meditation on how resentment, disgust, and shame have facilitated a moral sensibility toward neoliberal restructuring, Soldatic carefully documents statements by Australian Senators on responsibility and self-reliance which subtly blame disabled recipients of social assistance for their own marginalization. The statements articulate a vision of a social contract of equals, with disabled welfare recipients regarded as failing to keep up their end of the bargain. Soldatic also highlights the importance of portraying welfare recipients as disgusting, observing "The symbolic representation of this discourse visualises the undeserving welfare subject as fraudulent and morally corrupt" (p. 49). 
She notes the connections with the moral hygiene and eugenics movements of the early twentieth century and the often racialized disabled welfare recipients. Interestingly, she observes how welfare workers train disabled women to espouse a middle-class performance of respectability in order to gain greater acceptability. Finally, Soldatic shows how shame and humiliation experienced by disabled people enables the state bureaucracy to secure strict compliance with onerous rules, even when it involves a failure to make timely payments essential for disabled people to live.

Chapter 4 is an examination of temporal discourse in framing disability relations. Soldatic argues that a policy document, the McClure Report, uses temporal markers to create a sense of urgency for welfare reform. She rightly suggests that the effect is to normalize part-time work as the only practical solution for inclusion for disabled people, rather than find ways to instantiate the removal of systemic barriers, be they physical or attitudinal. Her attempt to show how time is used to recommodify disabled people's labour-power is also interesting, albeit schematic. In Chapter 5, Soldatic explores the impact of settler colonialism on Indigenous disabled people in Australia. While this topic merits an entire book, Soldatic attempts to convey a sense of the dispossession of Indigenous disabled peoples and their exclusion from labour markets. To her credit, she devotes time to discussing her methodology and has incorporated Indigenous voices in developing a research methodology that respects Indigenous ways of being, knowing, and doing. She captures the intergenerational impact of settler colonialism, such as a high prevalence of chronic disease and alcoholism and a lack of computer literacy, and how these issues shape the contemporary experiences of Indigenous peoples. A conclusion weaves the themes of the book together, warning against a return to the exclusionary Keynesian welfare state. 
Malhotra, Reviews of

The New Political Economy of Disability by van Toorn \& Disability and Neoliberal State Formations, by Soldatic CJDS 10.3 (November 2021)

Overall, Soldatic's book is very strong, deftly critiquing neoliberalism and filling a lacuna in the literature. Sometimes the writing is very dense, obscuring the meaning intended by the author. Conclusions are occasionally a bit choppy, perhaps reflecting the fact that some chapters were originally published in journals. Taken as a whole, however, both van Toorn and Soldatic make valuable contributions and offer insights that will be of interest to readers around the globe. Canadian disability studies scholars would do well to learn more about Australian realities and voices. 